\title{
Coupling solid phase microextraction to complementary separation platforms for metabotyping of $E$. coli metabolome in response to natural antibacterial agents
}

Fatemeh Mousavi $^{1}$, Emanuela Gionfriddo ${ }^{1}$, Eduardo Carasek $^{2}$, Erica A. Souza-Silva ${ }^{1, \#}$ and Janusz Pawliszyn ${ }^{1}$,*

1) Department of Chemistry, University of Waterloo, 200 University Avenue West, Waterloo, Ontario N2L 3G1, Canada

2) Department of Chemistry, Federal University of Santa Catarina, Florianópolis, Santa Catarina 88040-900, Brazil

* Corresponding Author

Tel.: +1-519-888-4641; Fax: +1-519-746-0435. E-mail: janusz@uwaterloo.ca

\#Current address: Universidade Federal do Rio Grande do Sul (UFRGS), Instituto de Química - Campus do Vale, Av. Bento Gonçalves, 9500, 91501-970 - Porto Alegre, RS Brasil

Abstract 
Introduction. Essential oils are known to possess antimicrobial activity; thus, their use has played an important role over the years in medicine and for food preservation purposes.

Objective. The effect of clove oil and its major constituents as bactericidal agents on the global metabolic profiling of $E$. coli bacteria was assessed by means of metabolic alterations, using solid phase microextraction (SPME) as a sample preparation method coupled to complementary analytical platforms.

Method. E. Coli cultures treated with clove oil and its major individual components were sampled by HS-SPME-GCxGC-ToF/MS and SPME-UPLC-MS. Full factorial design was applied in order to estimate the most effective antibacterial agent towards E. coli. Central composite design (CCD) and factorial design were applied to investigate parameters influencing metabolite coverage and efficiency by SPME.

Results. The metabolic profile, including 500 metabolites identified by LC-MS and 789 components detected by GCxGC-ToF/MS, 125 of which were identified as dysregulated metabolites, revealed changes in the metabolome provoked by the antibacterial activity of clove oil, and in particular its major constituent eugenol. Analyses of individual components selected using Orthogonal Projections to Latent Structures Discriminant Analysis (OPLS-DA) showed a neat differentiation between control samples in comparison to treated samples in various sets of metabolic pathways.

Conclusions. The combination of a sample preparation method capable of providing cleaner extracts coupled to different analytical platforms was successful in uncovering changes in metabolic pathways associated with lipids biodegradation, changes in the TCA cycle, amino acids, and enzyme inhibitors in response to antibacterial treatment.

Keywords: E.Coli, Solid Phase Microextraction, clove oil, metabolomics, LC-MS, GCxGC-ToF/MS 


\section{Introduction}

Owing to their antimicrobial characteristics, essential oils are widely used in medicine as well as in the food and fragrance industries. Their antibacterial, antiviral, insecticidal, antiparasitic, antifungal, and antioxidant properties are extensively documented (Astani et al. 2011; Brenes and Roura 2010; S. Burt 2004; Deans and Ritchie 1987; Kalemba and Kunicka 2003; Kim et al. 2003). Among the essential oils constituents, terpenes, terpenoids, phenol-derived aromatic components, and aliphatic compounds have been shown to diminish or interrupt the growth of bacteria, yeast, and mold through disruption of cell membrane and cytoplasm (S. A. Burt and Reinders 2003; Chorianopoulos et al. 2008; De Martino et al. 2009). Especially naturallyoccurring oxygenated terpenoids such as alcohols and phenolic terpenes have demonstrated the highest antimicrobial potential (S. Burt 2004; Delaquis 2002; Koroch et al. 2007; Smith-Palmer et al. 1998). In related work, 21 plant essential oils were applied as antibacterial agents against five food-borne pathogens (Campylobacter jejuni, Salmonella enteridis, E.coli, Staphylococcus aureus, and Listeria monocytogenes); their findings indicated that oils derived from bay, cinnamon, clove, and thyme yielded the highest bactericidal effect (Smith-Palmer et al. 1998). The interactions between different constituents of essential oils may lead to synergistic, antagonistic, indifference, or additive effects (Davidson and Parish 1989; K. Gill and Brown 2002). The mechanisms of action of these naturally-occurring compounds against pathogens are still not fully understood, especially at the metabolic level. As the metabolism of living systems alters in response to environmental stress, metabolomics platforms aim to provide complementary information to genomics, transcriptomics, and proteomics (Jozefczuk et al. 2010). Within this context, global analysis of all metabolites in a given system can be employed to discover potential biomarkers of specific effects or reactions (Dettmer et al.) attributable to specific stimuli. The global metabolomics platform includes different steps: sample preparation, instrumental analysis, and data analysis, where determinations of significant metabolite changes can be made using bioinformatics software. Due to the broad chemical and physical characteristics of metabolites, no single analytical platform could provide identification of all metabolites. Usually the most used instrumentation platforms for metabolomics are nuclear magnetic resonance (NMR) and mass spectrometry (MS), the latter coupled with both gas- (GC) and liquid-chromatography (LC). In addition, to increase method sensitivity and provide wider metabolome coverage, a proper sample preparation strategy, able to obtain the most representative, yet clean extract possible, needs to be used. Solid phase microextraction (SPME), as one of the recently emerging techniques utilized in sample preparation for metabolomics studies, is capable of fulfilling many of the criteria for ideal 
sample preparation in metabolomic investigations such us non-selectivity, reproducibility, simplicity and possibility for automation (Bojko et al. 2014; Vuckovic et al. 2011).

A crucial aspect of the metabolomics workflow, unfortunately often overlooked, is experimental planning. Considering that, untargeted metabolomics experiments involve the analysis of a consistent number metabolic features, often characterized by different physical-chemical properties, the optimization of each factor affecting their extraction, separation and detection needs to be carefully carried out, in order to find the proper operating conditions for the obtainment of representative sets of data. In particular, the currently presented work was undertaken using a statistical experimental design approach comprising careful design of experiments, including multivariate designs, that offer simultaneous optimization of several control variables, consequently taking into account interactions between factors and requiring fewer experiments than the traditional univariate approaches (Sousa et al. 2006).

The primary purpose of this study was to employ SPME coupled to GCxGC-ToF/MS and UPLCMS and bioinformatics tools to study changes in metabolic pathways of E. coli metabolome submitted to treatment with clove bud oil and its major constituents. Multivariate experimental design was applied to optimize factors that impact extraction and to evaluate the type of interactions occurring between the major active components of clove oil. Individual components of the clove oil were characterized and identified. Finally, the metabolic profiles of antibacterial agent-treated cells and control cells were generated by both optimized platforms and subjected to multivariate data analysis. These metabolic patterns produced clear separation between controls and treated samples on an OPLS-DA analysis due to up-regulated and down-regulated metabolites.

\section{Experimental section}

\subsection{Chemical and materials and Metabolite Standard Mixture Preparation}

Details regarding chemicals, materials and mixture preparation can be found in Supplementary Info (section 1.1)

\subsection{Bacterial strain and antibacterial activity evaluation}

Frozen cultures of $E$. coli BL21 were streaked on an LB agar media plate (10 g trypton; $5 \mathrm{~g}$ yeast extract; $5 \mathrm{~g} \mathrm{NaCl} ; 15 \mathrm{~g}$ Agar in $1 \mathrm{~L}$ nanopure water), and incubated overnight at $37{ }^{\circ} \mathrm{C}$. One isolated colony was re-streaked on LB Agar media and incubated at $37{ }^{\circ} \mathrm{C}$ for $24 \mathrm{~h}$. Following, one isolated colony was inoculated into $5 \mathrm{~mL}$ of LB media (10 g trypton; 5 g yeast extract; $5 \mathrm{~g} \mathrm{NaCl}$ in $1 \mathrm{~L}$ nanopure water), then incubated at $37^{\circ} \mathrm{C}$ for $24 \mathrm{~h}$ under agitation at 125 
rpm. The microbial broth was then serially diluted in fresh media. The resulting $10^{7}$ colonyforming units $(\mathrm{CFU} / \mathrm{mL})$ were utilized for the whole study.

LB agar media was used to count the number of $\mathrm{CFU} / \mathrm{mL}$ in bacterial media. Cultures were serially diluted with sterile media, and $10 \mu \mathrm{L}$ of diluted culture is spread uniformly over the surface of warm agar plates. After keeping plates in $37^{\circ} \mathrm{C}$ overnight, the colonies were counted. In order to get precise results, diluted cultures forming 30 to 100 colonies were applied for calculation of CFU/L.

To investigate the antibacterial activity of the most important constituent of clove bud oil, a twolevel full factorial design, $2^{3}$, was carried out. Table SI.2 shows the number of different possible conditions in this full factorial design experiment.

\subsection{Coating preparation, multivariate optimization of the 96-blade SPME method, and HS-SPME sampling conditions}

Prior to LC analyses, extractions automated by the robotic concept 96-autosampler were performed using a 96-blade SPME system consisted of PS-DVB-WAX:HLB 50:50 [w/w] as extraction phase coated onto stainless steel blades. Choice of coating and coating preparation procedure, information related to the concept 96-autosampler are reported elsewhere (Mousavi et al. 2015). Other details can be found in Supplementary Information (section 1.2)

\subsection{UHPLC-ESI-MS, GC-IT-MS and GCxGC-ToF-MS conditions}

For analyses an UPLC-Exactive (Thermo, San Jose, California, USA), a Varian CP-3800 GC system coupled to a Varian 4000 Ion-Trap Mass Spectrometer ( Varian, Palo Alto, California, USA) and a GCxGC-ToF/MS Pegasus 4D (METLIN) were used, further details concerning operational parameters and separation conditions can be found in Supplementary Information (section 1.3).

\subsection{Metabolite identification, data mining, and statistical analysis}

For LC based experiments, Raw data (.raw) obtained by Xcalibur software (version 2.1, Thermo, San Jose, California, USA) were converted to (mzXML) with MS conversion software. The converted data were then processed with a web-based platform, XCMS online (Scripps Center for Metabolomics, California, USA). The output consists in a table containing retention times, $\mathrm{m} / \mathrm{z}$ values, and intensity of features. XCMS identifies features whose relative intensity differs between sample groups, determining p-values as well as fold changes. The software carried out mass spectral peak deconvolution, alignment, peak picking (feature detection), and ion annotation on the list of features in order to identify the detected isotopes, adducts, and in-source fragment 
ions. Multivariate data analysis was carried out by SIMCA-P+ software (Umetrics, NJ, USA). Unsupervised principal component analysis (PCA) was used to evaluate grouping trends between the different antibacterial agent treatments. Orthogonal Projections to Latent Structures Discriminant Analysis (OPLS-DA) was performed on obtained data, and the resulting S-plots were inspected to investigate discriminant biomarkers produced in bacteria culture treated by antibacterial agents. Metabolite identities were specified based on their accurate mass, retention time, comparison of fragmentation data with authentic standards, and METLIN databases within $5 \mathrm{ppm}$. By the help of metabolite databases, it is applicable to find the $\mathrm{m} / \mathrm{z}$ ratio of peaks of interests manually. The KEGG database was used to identify important metabolic pathways and for biological interpretation. Identification can be confirmed applying $\mathrm{MS}^{2}$ fragmentation analysis. It is not practical to get standards of all compounds to do independent comparison. Therefore, quantification can be done through a relative comparison between groups applying statistics.

All acquired GCxGC-ToF/MS chromatograms were processed by ChromaTOF version 4.5 (LECO Corporation). Baseline correction, noise reduction, deconvolution, library matching, and peak area calculation were performed. Peak area calculations were performed using the unique mass of the detected analyte. Only peaks bearing $\mathrm{S} / \mathrm{N}$ ratio $\geq$ 100 were selected, and a spectral match threshold of 700 was selected for further data interpretation. Identification of selected entries was performed using the National Institute of Standards and Technology (NIST) reference library for matching of mass spectra, and by comparison of calculated retention indices with data present in literature.

The Statistical Compare feature of ChromaTOF was successively used for alignment of multidimensional peaks obtained from different chromatograms. Alignment parameters are specified in Supporting Information (Section 1.3). The obtained data tables (960 entries) were further manually scrutinized to remove peaks related to the extraction phase or chromatographic column bleeding (mainly siloxane-derived compound peaks), and to merge double entries, finally resulting in 789 entries. 
The obtained data sets were then processed by to SIMCA (version 14.0, Umetrics, Umea, Sweden) by performing PCA, and OPLS-DA in a similar manner as for the LC-based data.

Considering the large amount of intra- and inter- sample variation on metabolomics data, Hotelling T2 eclipse and DmodX were applied for outlier evaluation. With two component plots, T2 was easily visualized in score plots. Moderate outliers investigated in DmodX plots based on residuals observation.

\section{Results and discussion}

\subsection{Optimization of SPME parameters}

Optimization of desorption solvent was carried out using the model analytes presented in Table SI.1. Using the 96-blade SPME method, a triangular design was carried out to determine the effectiveness of different desorption solvents and their interactions on analyte recovery. The experimental design followed and the results obtained by CCD are reported in Supplemetary Information (Section 2.1).

\subsection{Interaction between clove oil components using full factorial design}

Once the 96-blade SPME method was optimized, a full factorial design was applied to investigate the effectiveness of constituents of clove bud in preventing E. coli metabolism, as well as to explore potential interactions between these major components.

Using GC-MS, the major components of clove bud oil were identified as eugenol (76.8\%), eugenyl acetate (9.5\%), and $\beta$-caryophyllene (6.0\%).

The minimum inhibitory concentration (MIC) threshold for clove oil was identified through addition of different amounts of clove oil to the same E. coli culture, followed by incubation at 37 ${ }^{\circ} \mathrm{C}$ for 16 hours. Afterwards 10 / $\mathrm{L}$ of treatment and sample solutions from each cell tube was plated all over the LB agar plates. Plates were incubated at $37^{\circ} \mathrm{C}$ overnight and colonies were counted in each case. Results indicated that $10 \mu \mathrm{L}$ was the MIC for clove oil for a $10^{7} \mathrm{CFU} / \mathrm{mL} E$. coli culture.

To evaluate the antibacterial activity of each constituent of clove oil against E.coli, different amounts of eugenol $(8 \mu \mathrm{L})$, eugenyl acetate $(1 \mu \mathrm{L})$ and $\beta$-caryophyllene $(0.6 \mu \mathrm{L})$ were separately added to the same concentration of bacteria in different cell tubes based on the percent of each component present in clove bud oil. No bacteria growth was observed for cultures treated with eugenol, while growth was observed for cultures treated with eugenyl acetate and $\beta$ caryophyllene, indicating eugenol as the most effective antibacterial agent in the whole oil. 
Metabolic profiling for each set of experiments was acquired; the variable effects and interactions between variables are summarized in the Pareto charts illustrated in Figure SI.3, SI.4 for SPMELC-MS and SI.5 for GC-IT/MS. The Pareto charts obtained for LC amenable metabolites ( Figures SI.3 and SI.4) reveal that eugenol, the major compound of clove bud oil, was found to possess the strongest antibacterial activity at the 95\% confidence level, whereas the other constituents, when applied individually, did not indicate an antibacterial effect on E. coli growth at the $95 \%$ confidence level.

By studying the volatile metabolic profiling, the same effect was monitored. Pareto chart plots based on sums of peak areas obtained from HS-SPME-GC-IT/MS for two metabolites, indol (downregulated) and octanoic acid (upregulated), are shown in Figure SI.5. Based on the results obtained from the Pareto charts, no significant interactions between the constituents for both platforms (at the 95\%confidence level) were observed.

\subsection{Metabolic profiling of $E$. coli under different compositions of antibacterial agents using 96-blade SPME LC-MS}

The obtained results indicated variations in the amounts (dysregulations) of some of the identified metabolites as a function of application of different compositions of antibacterial agents. Figures SI.6 and SI.7 demonstrates the LC-MS chromatograms of E.coli extract by the SPME coatings in positive and negative modes, respectively. Clove oil treatment sample extract chromatograms for both positive and negative ESI modes are shown by Figures SI.8 and SI.9, respectively. The output given by XCMS Online software is provided in Figure 1. Figure 1-D is a cloud plot demonstrating dysregulated features to represent ions whose intensities are varied between sample groups according to statistical thresholds. Down-regulated features in these treated samples are presented as red bubble-plots (bottom plot), while up-regulated features are represented by green bubble-plots (top plot).

About 10,000 features were detected in this study in both electrospray ionization modes, of which almost $60 \%$ of the peaks showed statistically significant changes due to treatment with antibacterial agents (clove oil and eugenol).

This discrimination in the metabolic profile of E. coli was not observed when eugenyl acetate, $\beta$ caryophellene, or a mixture of both was applied as antibacterial agents. As a proof of concept, a

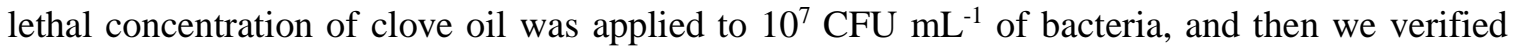
that the addition of eugenol alone in the same amount present in clove oil also prohibited bacteria growth. Conversely, individual additions of eugenyl acetate and $\beta$-caryophyllene at comparable 
amount of what added through clove oil, did not suffice to stop bacteria metabolism, and no interactions were observed between eugenol and the other two constituents towards E. coli growth. Table 1 demonstrates the dysregulated metabolites found in samples treated with clove oil and eugenol. In fact, in case of eugenol, belonging to the phenylpropene class, it has been demonstrated that the hydroxyl group present in the molecule plays an effective role in the prevention of bacterial growth (A. O. Gill et al. 2002; Hyldgaard et al. 2012). As a consequence, the antibacterial activity of eugenyl acetate is lower than that of eugenol, as there are no free hydroxyl groups in its structure. Phenylpropenes, which are synthesized by plants, can disrupt the metabolism of bacterial cells by forming hydrogen bonds through interactions with proteins (Laekeman et al. 1990). On the other hand, $\beta$-caryophyllene, a natural bicyclic sesquiterpene, showed low or absent antibacterial activity against E. coli (Koutsoudaki et al. 2005). In other studies, clove oil and eugenol indicated strong antibacterial activities in comparison to $\beta$ caryophyllene towards periodontopathogenic bacteria (Moon et al. 2011). In addition, information related to the effect of clove oil on the fatty acid profile of the E. coli cell membrane, on proteins and anti-quorum sensive activity are elucidated in Supplementary Information (Sections 2.1, 2.2, and 2.3)

\subsection{Effect of eugenol on VOC profile of E.coli}

Bacterial production of VOCs has been largely investigated (Schulz and Dickschat 2007). Bacterial volatile emissions are mainly related to by-products of metabolic pathways; for instance, the emission of hydrocarbons, aliphatic alcohols, and ketones derived from fatty acid biosynthesis. The VOC profile of E. coli was investigated by HS-SPME-GCxGC-ToF/MS, with particular emphasis on metabolic perturbations induced by the treatment of bacterial culture with clove oil and its major constituent eugenol. The bacterial VOC profile was determined in-vivo, with the SPME coating exposed to the headspace of E. Coli cultures incubated at $37^{\circ} \mathrm{C}$, under agitation at $500 \mathrm{rpm}$, and during the stationary phase of the bacteria growth cycle (8 to 16 hours after sample preparation). The chromatograms obtained from bacteria culture before and after treatment with eugenol and clove oil are presented in Supplementary Information (Figure SI.10). The results obtained were processed by SIMCA software; PCA (Figure SI.11) and OPLS-DA (Figure 2) revealed a neat differentiation between non-treated samples, and samples treated with whole clove oil or eugenol only. From the S-plots, presented in Figures 2-c and 2-d, the features that mostly contributed to the separation of the investigated sets of samples were selected and further investigated. While the production of terpenoids by bacteria has already been reported 
(Schulz and Dickschat 2007), in this study, the complex composition of the essential oil used to treat the bacterial culture made the process of distinguishing between bacterial-produced terpenoids and compounds deriving from the essential oil unreliable, as well as assessing the extent to which changes in their concentrations were exclusively related to the alteration of bacterial metabolism due to the antibacterial agents. Thus this class of compounds was not considered. Table 2 shows a list of the tentatively identified bacterial VOCs that most contributed to discrimination between cultures of $E$. coli in the presence or absence of antibacterial agents. Results demonstrated that variations in the amounts of metabolites (a decrease or increase in chromatographic areas) were dependent on the application of different compositions of antibacterial agents. As evidenced in Table 2, the compounds most affected by treatment with antibacterial agents were derivatives formed along the fatty acid biosynthetic pathway (Schulz and Dickschat 2007), such as alcohols, ketones, and esters. In particular, methyl ketones with an odd number of carbon atoms were reported to derive from the decarboxylation of even-numbered $\beta$-keto acids. The production of methyl ketones bearing an even number of atoms rarely occurs, since they derive from odd numbered fatty acids; however, production of 2-butanone has also been reported as a component of VOC emissions from several bacteria (DeMilo et al. 1996; Dickschat, Martens, et al. 2005; Elgaali et al. 2002; Lee et al. 1995; Robacker and Bartelt 1997; Sunesson et al. 1997). Esters also constitute a very important class of bacterial VOCs, and their enhanced volatility compared to their precursor carboxylic acids facilitates their determination by headspace sampling and gas-chromatographic analysis. Among the different esters detected, ethyl octanoate has already been reported as one of the constituents of E. coli VOC emissions (Elgaali et al. 2002). On the other hand, emission of aldehydes, especially unbranched aldehydes, rarely occurs owing to their reactivity. In this work, the aldehydes whose concentrations were mostly affected by treatment with clove oil and eugenol were furfural, benzaldehyde, and nonanal. Benzaldehyde production can be related to two different pathways, leading to the conversion of L-phenylalanine to benzoyl-CoA, whereas nonanal derives from oxidation of oleic acid. Other compounds deriving from L-tryptophan detected in this work were indole and 2,5dimethylpyrazine. In particular, the presence of pyrazines bearing one to four methyl substituents is widespread, and generally reported in the literature (Dickschat, Bode, et al. 2005; Dickschat, Reichenbach, et al. 2005; Schulz et al. 2004). Dysregulation of various VOC metabolites in treated samples demonstrated the effect of eugenol on several metabolic pathways of E. coli due to its interaction on different biological compartments, such as the cellular membrane. Considering this, alterations in the respiratory pathway of E. coli could be monitored by 
investigating metabolites with a high vapor pressure escaping from liquid media with the use of headspace SPME. Previously, metabolome analysis by Cox et al. demonstrated that E.coli treatment by carvacrol changed respiration to fermentation, and caused $\mathrm{K}+$ leakage (Cox et al. 1998). For example, decreases in indol, thiazol, methanethiol, and butanone levels demonstrate disruptions in tryptophan, thiamine, cysteine, methionine (and other amino acid-containing sulfurs), and riboflavin metabolism, respectively. Additionally, the levels of esters were also noticed to increase in treated samples. All the above-mentioned alterations in the volatomic profile could be attributed to the inhibition effect of eugenol on enzymes such as tryptophanase and lipoxygenase, due to deamination and termination or reduction of decarboxylation and.

Further interpretation of the observed changes would require a more comprehensive investigation and interpretation of biochemical pathways of $E$. coli growing under clove oil treatment, including integration of other 'omics' branches, such as transcriptomics and proteomics.

\section{Conclusion}

The current work demonstrated the suitability of Solid-Phase Microextraction as a reliable tool for the capture of variations of $E$. Coli metabolome and volatilome in response to natural antibacterial agents such as clove oil and its major component eugenol. Here, multivariate data analysis tools were successfully employed to investigate the $E$. coli metabolome profile under mild and severe stress conditions induced by these naturally-occurring antibacterial agents. SPME applied as a sample preparation technique provides clean extracts from complex biological samples, while allowing for its coupling to complementary separation platforms, as herein proposed for untargeted metabolomics strategies. The use of SPME coupled to GCxGC-ToF/MS and UPLC-MS provides a comprehensive metabolome snapshot of metabolites with a wide variety of physical and chemical characteristics, including volatiles, polar, and nonpolar metabolites, thus enhancing the amount of chemical information retrievable from the system under investigation in comparison to conventional extraction techniques. In the current work, shifts in different pathways involved in lipid, carbohydrate, and amino acid metabolisms, as well as cell signaling variations were monitored for treated and control samples. New alterations in the E. coli metabolic pathways as a function of treatment by clove oil have been suggested in this study, such as changes in proline and glycerol levels attributed to cell osmoregulation. Evaluation of the discriminant metabolites in treated samples confirmed that eugenol is a lead candidate for further development as an active agent in anti-cancer treatments, owing to its ability to cause glycolysis inhibition of $E$. coli as a model organism. Changes in different metabolite levels and pathways identified from our approach confirms the interaction of clove oil with various enzymes 
in the model system biology, as well as the capacity of metabolomics to identify the influence of stressors on microorganisms. This approach offers a valid option for future analyses seeking to establish a comprehensive mechanistic understanding of $E$. coli response to clove oil.

\section{Acknowledgments}

The authors thank the Natural Sciences and Engineering Research Council (NSERC) of Canada for financial support, PAS Technology for the Concept 96-blade device and autosampler, and Prof. Mark Servos from the University of Waterloo for his permission to use the facilities in his laboratory at the Department of Biology. The authors also wish to acknowledge Dr. Richard Smith, Nathaly Reyes-Garces, Dr. Barbara Bojko, Dr. Angel Rodriguez Lafuente, and Dr. Selenia De Grazia for their kind help. E.G. and E.A.S.S. greatly appreciate the technical support of Olivier Niquette and KC Walbank with the GCxGC-ToF/MS system. E. C. thanks CNPq (Conselho Nacional de Desenvolvimento Cientifico e Tecnologico) for the post-doctoral fellowship.

\section{Compliance with Ethical Standards:}

Funding: This study was funded by Natural Sciences and Engineering Research Council (NSERC) of Canada. E. C. received his postdoctoral fellowship from CNPq (Conselho Nacional de Desenvolvimento Cientifico e Tecnologico), Brazil.

Conflict of interests: F. Mousavi declares that she has no conflict of interest. E. Gionfriddo declares that she has no conflict of interest. E. Carasek declares that he has no conflict of interest. E. A. Souza-Silva declares that she has no conflict of interest. J. Pawliszyn declares that he has no conflict of interest.

Ethical approval: This article does not contain any studies with human participants or animals performed by any of the authors.

\section{References}

Astani, A., Reichling, J., \& Schnitzler, P. (2011). Screening for antiviral activities of isolated 
compounds from essential oils. Evidence-based Complementary and Alternative Medicine, 2011. doi:10.1093/ecam/nep187

Bojko, B., Reyes-Garcés, N., Bessonneau, V., Goryński, K., Mousavi, F., Souza Silva, E. A., \& Pawliszyn, J. (2014). Solid-phase microextraction in metabolomics. TrAC Trends in Analytical Chemistry, 61, 168-180. doi:10.1016/j.trac.2014.07.005

Brenes, A., \& Roura, E. (2010). Essential oils in poultry nutrition: Main effects and modes of action. Animal Feed Science and Technology, 158(1-2), 1-14. doi:10.1016/j.anifeedsci.2010.03.007

Burt, S. (2004). Essential oils: their antibacterial properties and potential applications in foods--a review. International journal of food microbiology, 94(3), 223-53. doi:10.1016/j.ijfoodmicro.2004.03.022

Burt, S. A., \& Reinders, R. D. (2003). Antibacterial activity of selected plant essential oils against Escherichia coli O157:H7. Letters in Applied Microbiology, 36(3), 162-167. doi:10.1046/j.1472-765X.2003.01285.X

Chorianopoulos, N. G., Giaouris, E. D., Skandamis, P. N., Haroutounian, S. A., \& Nychas, G.-J. E. (2008). Disinfectant test against monoculture and mixed-culture biofilms composed of technological, spoilage and pathogenic bacteria: bactericidal effect of essential oil and hydrosol of Satureja thymbra and comparison with standard acid-base sanitizers. Journal of applied microbiology, 104(6), 1586-96. doi:10.1111/j.1365-2672.2007.03694.X

Cox, S. D., Gustafson, J. E., Mann, C. M., Markham, J. L., Liew, Y. C., \& Hartland, R. P. (1998). Tea tree oil causes $\mathrm{K}+$ leakage and inhibits respiration in Escherichia coli. Letters in Applied Microbiology, 26(5), 355-358. doi:10.1046/j.1472-765X.1998.00348.X

Davidson, P. M., \& Parish, M. E. (1989). Methods for testing the efficacy of food antimicrobials. Food technology, 43(1), 148-155.

De Martino, L., De Feo, V., \& Nazzaro, F. (2009). Chemical composition and in vitro antimicrobial and mutagenic activities of seven Lamiaceae essential oils. Molecules (Basel, Switzerland), 14(10), 4213-30. doi:10.3390/molecules14104213

Deans, S. G., \& Ritchie, G. (1987). Antibacterial properties of plant essential oils. International Journal of Food Microbiology, 5(2), 165-180. doi:10.1016/0168-1605(87)90034-1

Delaquis, P. (2002). Antimicrobial activity of individual and mixed fractions of dill, cilantro, coriander and eucalyptus essential oils. International Journal of Food Microbiology, 74(12), 101-109. doi:10.1016/S0168-1605(01)00734-6

DeMilo, A. B., Lee, C.-J., Moreno, D. S., \& Martinez, A. J. (1996). Identification of Volatiles 
Derived from Citrobacter freundii Fermentation of a Trypticase Soy Broth. Journal of Agricultural and Food Chemistry, 44(2), 607-612. doi:10.1021/jf950525o

Dettmer, K., Aronov, P. A., \& Hammock, B. D. Mass spectrometry-based metabolomics. Mass spectrometry reviews, 26(1), 51-78. doi:10.1002/mas.20108

Dickschat, J. S., Bode, H. B., Wenzel, S. C., Müller, R., \& Schulz, S. (2005). Biosynthesis and identification of volatiles released by the myxobacterium Stigmatella aurantiaca.

Chembiochem : a European journal of chemical biology, 6(11), 2023-33. doi:10.1002/cbic.200500174

Dickschat, J. S., Martens, T., Brinkhoff, T., Simon, M., \& Schulz, S. (2005). Volatiles released by a Streptomyces species isolated from the North Sea. Chemistry \& biodiversity, 2(7), 83765. doi:10.1002/cbdv.200590062

Dickschat, J. S., Reichenbach, H., Wagner-Döbler, I., \& Schulz, S. (2005). Novel Pyrazines from the MyxobacteriumChondromyces crocatus and Marine Bacteria. European Journal of Organic Chemistry, 2005(19), 4141-4153. doi:10.1002/ejoc.200500280

Elgaali, H., Hamilton-Kemp, T. R., Newman, M. C., Collins, R. W., Yu, K., \& Archbold, D. D. (2002). Comparison of long-chain alcohols and other volatile compounds emitted from food-borne and related Gram positive and Gram negative bacteria. Journal of basic microbiology, 42(6), 373-80. doi:10.1002/1521-4028(200212)42:6<373::AIDJOBM373>3.0.CO;2-4

Gill, A. O., Delaquis, P., Russo, P., \& Holley, R. . (2002). Evaluation of antilisterial action of cilantro oil on vacuum packed ham. International Journal of Food Microbiology, 73(1), 8392. doi:10.1016/S0168-1605(01)00712-7

Gill, K., \& Brown, W. a. (2002). Extending the solid-phase microextraction technique to high analyte concentrations: measurements and thermodynamic analysis. Analytical chemistry, 74(5), 1031-7. http://www.ncbi.nlm.nih.gov/pubmed/11924960

Hyldgaard, M., Mygind, T., \& Meyer, R. L. (2012). Essential oils in food preservation: mode of action, synergies, and interactions with food matrix components. Frontiers in microbiology, 3, 12. doi:10.3389/fmicb.2012.00012

Jozefczuk, S., Klie, S., Catchpole, G., Szymanski, J., Cuadros-Inostroza, A., Steinhauser, D., et al. (2010). Metabolomic and transcriptomic stress response of Escherichia coli. Molecular systems biology, 6(1), 364. doi:10.1038/msb.2010.18

Kalemba, D., \& Kunicka, A. (2003). Antibacterial and antifungal properties of essential oils. Current medicinal chemistry, 10(10), 813-29. 
Kim, S.-I., Roh, J.-Y., Kim, D.-H., Lee, H.-S., \& Ahn, Y.-J. (2003). Insecticidal activities of aromatic plant extracts and essential oils against Sitophilus oryzae and Callosobruchus chinensis. Journal of Stored Products Research, 39(3), 293-303. doi:10.1016/S0022474X(02)00017-6

Koroch, A., Juliani, H. R., \& Zygadlo, J. A. (2007). Bioactivity of Essential Oils and Their Components. (R. G. Berger, Ed.). Berlin, Heidelberg: Springer Berlin Heidelberg. doi:10.1007/978-3-540-49339-6

Koutsoudaki, C., Krsek, M., \& Rodger, A. (2005). Chemical composition and antibacterial activity of the essential oil and the gum of Pistacia lentiscus Var. chia. Journal of agricultural and food chemistry, 53(20), 7681-5. doi:10.1021/jf050639s

Laekeman, G. M., van Hoof, L., Haemers, A., Berghe, D. A. Vanden, Herman, A. G., \& Vlietinck, A. J. (1990). Eugenol a valuable compound forin vitro experimental research and worthwhile for furtherin vivo investigation. Phytotherapy Research, 4(3), 90-96. doi:10.1002/ptr.2650040304

Lee, C.-J., DeMilo, A. B., Moreno, D. S., \& Martinez, A. J. (1995). Analysis of the volatile components of a bacterial fermentation attractive to the mexican fruit fly (Anastrepha ludens). Journal of Agricultural and Food Chemistry, 43(5), 1348-1351. doi:10.1021/jf00053a041

Moon, S.-E., Kim, H.-Y., \& Cha, J.-D. (2011). Synergistic effect between clove oil and its major compounds and antibiotics against oral bacteria. Archives of oral biology, 56(9), 907-16. doi:10.1016/j.archoralbio.2011.02.005

Mousavi, F., Bojko, B., \& Pawliszyn, J. (2015). Development of high throughput 96-blade solid phase microextraction-liquid chromatrography-mass spectrometry protocol for metabolomics. Analytica chimica acta, 892, 95-104. doi:10.1016/j.aca.2015.08.016

Robacker, D. C., \& Bartelt, R. J. (1997). Chemicals Attractive to Mexican Fruit Fly from Klebsiella pneumoniae and Citrobacter freundii. Cultures Sampled by Solid-Phase Microextraction. Journal of Chemical Ecology, 23(12), 2897-2915. doi:10.1023/A:1022579414233

Schulz, S., \& Dickschat, J. S. (2007). Bacterial volatiles: the smell of small organisms. Natural product reports, 24(4), 814-842.

Schulz, S., Fuhlendorff, J., \& Reichenbach, H. (2004). Identification and synthesis of volatiles released by the myxobacterium Chondromyces crocatus. Tetrahedron, 60(17), 3863-3872. doi:10.1016/j.tet.2004.03.005 
Smith-Palmer, A., Stewart, J., \& Fyfe, L. (1998). Antimicrobial properties of plant essential oils and essences against five important food-borne pathogens. Letters in Applied Microbiology, 26(2), 118-122. doi:10.1046/j.1472-765X.1998.00303.X

Sousa, E. T., de M. Rodrigues, F., Martins, C. C., de Oliveira, F. S., de P. Pereira, P. A., \& de Andrade, J. B. (2006). Multivariate optimization and HS-SPME/GC-MS analysis of VOCs in red, yellow and purple varieties of Capsicum chinense sp. peppers. Microchemical Journal, 82(2), 142-149. doi:10.1016/j.microc.2006.01.017

Sunesson, A.-L., Nilsson, C.-A., Carlson, R., Blomquist, G., \& Andersson, B. (1997). Production of volatile metabolites from streptomyces albidoflavus cultivated on gypsum board and tryptone glucose extract agar--influence of temperature, oxygen and carbon dioxide levels. Annals of Occupational Hygiene, 41(4), 393-413. doi:10.1093/annhyg/41.4.393

Vuckovic, D., de Lannoy, I., Gien, B., Shirey, R. E., Sidisky, L. M., Dutta, S., \& Pawliszyn, J. (2011). In vivo solid-phase microextraction: capturing the elusive portion of metabolome. Angewandte Chemie (International ed. in English), 50(23), 5344-8. doi:10.1002/anie.201006715

\section{Figure Captions}

Fig. 1 XCMS online output. total ion chromatograms (TICs) before (A) and after (B) retention time correction. C: retention time deviation versus retention time for different analyzed samples. D: cloud plot: down-regulated (red bubbles) and up-regulated (green bubbles) features of E.coli sample treated by eugenol 
Fig. 2 Score plot corresponding to OPLS-DA analysis of A) media+bacteria (green dots) vs. media+bacteria+clove oil (red dots) and B) media+bacteria (green dots) vs. media+bacteria+eugenol (blue dots) and corresponding S-plots C) and D).

\section{Tables}


Table 1 Dysregulated metabolites in E.coli samples treated by clove oil and eugenol, obtained with 96-blade SPME-LC/MS. Up-regulated metabolites are shown in red, while down-regulated metabolites are demonstrated in blue.

\begin{tabular}{|c|c|c|c|c|c|c|}
\hline Metabolite & Adduct & $\mathbf{m z}$ & $\begin{array}{l}\text { METLIN } \\
\text { ID }\end{array}$ & $\begin{array}{c}\text { Mass } \\
\text { accuracy }\end{array}$ & $\begin{array}{l}\text { Chemical } \\
\text { Formula }\end{array}$ & $\begin{array}{l}\text { Regulation } \\
\text { p-value }\end{array}$ \\
\hline \multicolumn{7}{|c|}{ Amino Acids and Derivatives } \\
\hline Proline & {$[\mathrm{M}+\mathrm{H}]^{+}$} & 116.0707 & 58150 & 0.8 & $\mathrm{C}_{5} \mathrm{H}_{9} \mathrm{NO}_{2}$ & $6.64574 \mathrm{e}-6$ \\
\hline Asparagine & {$[\mathrm{M}+\mathrm{H}]^{+}$} & 133.0608 & 65674 & 0 & $\mathrm{C}_{4} \mathrm{H}_{8} \mathrm{~N}_{2} \mathrm{O}_{3}$ & 7.37334e-6 \\
\hline Tryptophan & {$[\mathrm{M}+\mathrm{H}]^{+}$} & 205.0966 & 33 & 2 & $\begin{array}{c}\mathrm{C}_{11} \mathrm{H}_{12} \mathrm{~N}_{2} \mathrm{O} \\
2\end{array}$ & 0.00345 \\
\hline N-Hydroxy-L-tryptophan & {$[\mathrm{M}+\mathrm{H}]^{+}$} & 221.0920 & 73314 & 0 & $\begin{array}{c}\mathrm{C}_{11} \mathrm{H}_{12} \mathrm{~N}_{2} \mathrm{O} \\
3\end{array}$ & $9.57623 e-6$ \\
\hline Valine & {$[\mathrm{M}+\mathrm{H}]^{+}$} & 118.0864 & 71199 & 0.8 & $\mathrm{C}_{5} \mathrm{H}_{11} \mathrm{NO}_{2}$ & 0.00008 \\
\hline Tyrosine & {$[\mathrm{M}+\mathrm{NH} 4]^{+}$} & 199.1078 & 58353 & 0 & $\mathrm{C}_{9} \mathrm{H}_{11} \mathrm{NO}_{3}$ & 0.00019 \\
\hline Homoarginine & {$[\mathrm{M}+\mathrm{H}]^{+}$} & 189.1343 & 5640 & -1.6 & $\mathrm{C}_{7} \mathrm{H}_{16} \mathrm{~N}_{4} \mathrm{O}_{2}$ & 0.00019 \\
\hline Homoglutamine & {$[\mathrm{M}+\mathrm{H}]^{+}$} & 161.0920 & 3281 & 0 & $\mathrm{C}_{6} \mathrm{H}_{12} \mathrm{~N}_{2} \mathrm{O}_{3}$ & 0.00021 \\
\hline Serine & {$[\mathrm{M}+\mathrm{H}]^{+}$} & 106.0501 & 63419 & 2.8 & $\mathrm{C}_{3} \mathrm{H}_{7} \mathrm{NO}_{3}$ & 0.00001 \\
\hline Glutamate & {$[\mathrm{M}+\mathrm{H}]^{+}$} & 148.0604 & 3761 & 0 & $\mathrm{C}_{5} \mathrm{H}_{9} \mathrm{NO}_{4}$ & 0.00014 \\
\hline $\begin{array}{c}\text { Citrulline } \\
\text { Na-Acetyl-L-arginine }\end{array}$ & $\begin{array}{c}{[\mathrm{M}+\mathrm{ACN}+} \\
\mathrm{H}]^{+} \\
{[\mathrm{M}+\mathrm{H}]^{+}}\end{array}$ & 217.1295 & 16 & 0 & $\mathrm{C}_{6} \mathrm{H}_{13} \mathrm{~N}_{3} \mathrm{O}_{3}$ & 0.00014 \\
\hline Histidine & $\begin{array}{c}{[\mathrm{M}+2 \mathrm{Na}-} \\
\mathrm{H}]^{+}\end{array}$ & 200.0403 & 65529 & -1.5 & $\mathrm{C}_{6} \mathrm{H}_{9} \mathrm{~N}_{3} \mathrm{O}_{2}$ & 0.00005 \\
\hline Aspartic acid & {$[\mathrm{M}+\mathrm{H}]^{+}$} & 134.0448 & 63097 & 0 & $\mathrm{C}_{4} \mathrm{H}_{7} \mathrm{NO}_{4}$ & 0.00003 \\
\hline $\begin{array}{l}\text { N6-Acetyl-N6-hydroxy-L- } \\
\text { lysine }\end{array}$ & {$[\mathrm{M}+\mathrm{H}]^{+}$} & 205.1182 & 63465 & 0 & $\mathrm{C}_{8} \mathrm{H}_{16} \mathrm{~N}_{2} \mathrm{O}_{4}$ & 0.00007 \\
\hline Threonine & {$[\mathrm{M}+\mathrm{H}]^{+}$} & 120.0656 & 32 & 0 & $\mathrm{C}_{4} \mathrm{H}_{9} \mathrm{NO}_{3}$ & 0.00007 \\
\hline \multicolumn{7}{|c|}{ Azolines } \\
\hline Creatinine & $\begin{array}{c}{[\mathrm{M}+\mathrm{ACN}+} \\
\mathrm{H}]^{+}\end{array}$ & 155.0927 & 8 & 0 & $\mathrm{C}_{4} \mathrm{H}_{7} \mathrm{~N}_{3} \mathrm{O}$ & $9.74675 e-6$ \\
\hline \multicolumn{7}{|c|}{ Benzene and Substituted Derivatives } \\
\hline Phoxim & $\begin{array}{c}{[\mathrm{M}+2 \mathrm{Na}-} \\
\mathrm{H}]^{+}\end{array}$ & 343.0254 & \begin{tabular}{c|c}
725 \\
30
\end{tabular} & 1.6 & $\begin{array}{c}\mathrm{C}_{12} \mathrm{H}_{15} \mathrm{~N}_{2} \mathrm{O} \\
{ }_{3} \mathrm{PS}\end{array}$ & 0.00227 \\
\hline \multicolumn{7}{|c|}{ Carbohydrates and carbohydrate conjugates } \\
\hline Acetylmannosamine & {$[\mathrm{M}+\mathrm{H}]^{+}$} & 222.0973 & \begin{tabular}{|c|c|}
335 \\
7
\end{tabular} & 0.5 & $\mathrm{C}_{8} \mathrm{H}_{15} \mathrm{NO}_{6}$ & 0.00002 \\
\hline Glucose & {$[\mathrm{M}+\mathrm{Na}]^{+}$} & 203.0527 & $\begin{array}{c}631 \\
18\end{array}$ & 0.5 & $\mathrm{C}_{6} \mathrm{H}_{12} \mathrm{O} 6$ & 0.00004 \\
\hline Sucrose & $\begin{array}{l}{[\mathrm{M}+\mathrm{H}-} \\
\mathrm{H} 2 \mathrm{O}]^{+}\end{array}$ & 325.1129 & 137 & -1.5 & $\mathrm{C}_{12} \mathrm{H}_{22} \mathrm{O}_{11}$ & $1.17474 \mathrm{e}-6$ \\
\hline
\end{tabular}




\begin{tabular}{|c|c|c|c|c|c|c|}
\hline Glucosaminide & $\begin{array}{l}{[\mathrm{M}+\mathrm{H}-} \\
2 \mathrm{H} 2 \mathrm{O}]^{+}\end{array}$ & 466.2041 & $\begin{array}{c}704 \\
3\end{array}$ & 1.1 & $\begin{array}{c}\mathrm{C}_{18} \mathrm{H}_{35} \mathrm{~N}_{3} \mathrm{O} \\
13\end{array}$ & 0.00003 \\
\hline \multicolumn{7}{|c|}{ Carboxylic Acids and Derivatives } \\
\hline N-Acetylcystathionine & $\begin{array}{l}{[\mathrm{M}+\mathrm{H}-} \\
\mathrm{H} 2 \mathrm{O}]^{+}\end{array}$ & 247.0748 & $\begin{array}{c}665 \\
6\end{array}$ & 1.6 & $\begin{array}{c}\mathrm{C}_{9} \mathrm{H}_{16} \mathrm{~N}_{2} \mathrm{O}_{5} \\
\mathrm{~S}\end{array}$ & $1.48854 \mathrm{e}-6$ \\
\hline Lysopine & {$[\mathrm{M}+\mathrm{H}]^{+}$} & 219.1340 & $\begin{array}{c}894 \\
68\end{array}$ & 0 & $\mathrm{C}_{9} \mathrm{H}_{18} \mathrm{~N}_{2} \mathrm{O}_{4}$ & 0.00368 \\
\hline Adipic acid & {$[\mathrm{M}+\mathrm{Na}]^{+}$} & 169.0468 & 115 & -1.7 & $\mathrm{C}_{6} \mathrm{H}_{10} \mathrm{O}_{4}$ & 0.00055 \\
\hline Cystine & {$[\mathrm{M}+\mathrm{H}]^{+}$} & 241.0310 & $\begin{array}{c}636 \\
35\end{array}$ & 0.4 & $\begin{array}{c}\mathrm{C}_{6} \mathrm{H}_{12} \mathrm{~N}_{2} \mathrm{O}_{4} \\
\mathrm{~S}_{2}\end{array}$ & 0.00153 \\
\hline Glutathione & {$[\mathrm{M}+\mathrm{H}]^{+}$} & 308.0909 & 44 & 0.3 & $\begin{array}{c}\mathrm{C}_{10} \mathrm{H}_{17} \mathrm{~N}_{3} \mathrm{O} \\
{ }_{6} \mathrm{~S}\end{array}$ & 0.00033 \\
\hline N-Acetylcadaverine & {$[\mathrm{M}+\mathrm{H}]^{+}$} & 145.1336 & $\begin{array}{c}659 \\
2\end{array}$ & 0.7 & $\mathrm{C}_{7} \mathrm{H}_{16} \mathrm{~N}_{2} \mathrm{O}$ & 0.00026 \\
\hline $\begin{array}{c}\gamma \text {-Glutamyl- } \gamma \text { - } \\
\text { aminobutyraldehyde }\end{array}$ & {$[\mathrm{M}+\mathrm{H}]^{+}$} & 217.1183 & $\begin{array}{c}634 \\
81\end{array}$ & 0 & $\mathrm{C}_{9} \mathrm{H}_{16} \mathrm{~N}_{2} \mathrm{O}_{4}$ & 0.00119 \\
\hline Diaminopimelic acid & {$[\mathrm{M}+\mathrm{H}]^{+}$} & 191.1027 & 352 & 0.5 & $\mathrm{C}_{7} \mathrm{H}_{14} \mathrm{~N}_{2} \mathrm{O}_{4}$ & 0.00342 \\
\hline Homocitrulline & {$[\mathrm{M}]^{+}$} & 189.1116 & 46 & 1.5 & $\mathrm{C}_{7} \mathrm{H}_{15} \mathrm{~N}_{3} \mathrm{O}_{3}$ & $3.84520 \mathrm{e}-6$ \\
\hline \multicolumn{7}{|c|}{ Diazines } \\
\hline Cytosine & {$[\mathrm{M}+\mathrm{H}]^{+}$} & 112.0507 & 283 & 1.7 & $\mathrm{C}_{4} \mathrm{H}_{5} \mathrm{~N}_{3} \mathrm{O}$ & 0.00016 \\
\hline \multicolumn{7}{|c|}{ Fatty Acids and Conjugates } \\
\hline 2-keto valeric acid & $\begin{array}{c}{[\mathrm{M}+\mathrm{ACN}+} \\
\mathrm{H}]^{+}\end{array}$ & 158.0811 & $\begin{array}{c}324 \\
3\end{array}$ & 0 & $\mathrm{C}_{5} \mathrm{H}_{8} \mathrm{O}_{3}$ & 0.00245 \\
\hline $\begin{array}{l}\text { 2E,4E-dodecadienoic acid } \\
\text { (unsaturated) }\end{array}$ & {$[\mathrm{M}+\mathrm{H}]^{+}$} & 197.1538 & $\begin{array}{c}348 \\
95\end{array}$ & -1.0 & $\mathrm{C}_{12} \mathrm{H}_{20} \mathrm{O}_{2}$ & 0.00011 \\
\hline $\begin{array}{c}\text { 4,7,10-hexadecatrienoic } \\
\text { acid } \\
\text { (unsaturated) }\end{array}$ & {$[\mathrm{M}+\mathrm{H}]^{+}$} & 251.2007 & $\begin{array}{c}348 \\
09\end{array}$ & 0.8 & $\mathrm{C}_{16} \mathrm{H}_{26} \mathrm{O}_{2}$ & 0.00010 \\
\hline $\begin{array}{l}\text { dihydroxy-stearic acid } \\
\text { (saturated) }\end{array}$ & {$[\mathrm{M}+\mathrm{Na}]^{+}$} & 339.2509 & $\frac{458}{32}$ & 1.2 & $\mathrm{C}_{18} \mathrm{H}_{36} \mathrm{O}_{4}$ & 0.00001 \\
\hline $\begin{array}{l}\text { nonadienoic acid } \\
\text { (unsaturated) }\end{array}$ & {$[\mathrm{M}+\mathrm{NH} 4]^{+}$} & 172.1332 & $\begin{array}{c}351 \\
03\end{array}$ & 0 & $\mathrm{C}_{9} \mathrm{H}_{14} \mathrm{O}_{2}$ & 0.00024 \\
\hline $\begin{array}{l}\text { hydroxypalmitic acid } \\
\text { (saturated) }\end{array}$ & {$[\mathrm{M}-\mathrm{H}]^{-}$} & 271.2265 & $\begin{array}{c}458 \\
29\end{array}$ & -4.7 & $\begin{array}{c}\mathrm{C} 16 \mathrm{H} 32 \mathrm{O} \\
3\end{array}$ & 0.0001 \\
\hline $\begin{array}{l}\text { Isodecenoic acid } \\
\text { (unsaturated) }\end{array}$ & {$[\mathrm{M}+\mathrm{H}]^{+}$} & 171.1380 & $\begin{array}{c}347 \\
22\end{array}$ & 0 & $\mathrm{C}_{10} \mathrm{H}_{18} \mathrm{O}_{2}$ & 0.00015 \\
\hline $\begin{array}{l}\text { tridecadienoic acid } \\
\text { (unsaturated) }\end{array}$ & $\begin{array}{l}{[\mathrm{M}+\mathrm{H}-} \\
\mathrm{H} 2 \mathrm{O}]^{+}\end{array}$ & 193.1588 & $\begin{array}{c}349 \\
09\end{array}$ & 2.1 & $\mathrm{C}_{13} \mathrm{H}_{22} \mathrm{O}_{2}$ & 193.1588 \\
\hline $\begin{array}{l}\text { dodecadienoic acid } \\
\text { (unsaturated) }\end{array}$ & {$[\mathrm{M}+\mathrm{H}]^{+}$} & 197.1538 & $\begin{array}{c}348 \\
95\end{array}$ & -1.3 & $\mathrm{C}_{12} \mathrm{H}_{20} \mathrm{O}_{2}$ & 0.00004 \\
\hline
\end{tabular}




\begin{tabular}{|c|c|c|c|c|c|c|}
\hline $\begin{array}{l}\text { Myristoleic acid } \\
\text { (unsaturated) }\end{array}$ & {$[\mathrm{M}+\mathrm{H}]^{+}$} & 227.2007 & $\begin{array}{c}642 \\
4\end{array}$ & 0.8 & $\mathrm{C}_{14} \mathrm{H}_{26} \mathrm{O}_{2}$ & 0.00496 \\
\hline Myristic Acid Alkyne & $\begin{array}{l}{[\mathrm{M}+\mathrm{H}-} \\
\mathrm{H} 2 \mathrm{O}]^{+}\end{array}$ & 207.1745 & $\begin{array}{c}352 \\
48\end{array}$ & -1.9 & $\mathrm{C}_{14} \mathrm{H}_{24} \mathrm{O}_{2}$ & 0.00190 \\
\hline Decatetraenedioic acid & {$[\mathrm{M}+\mathrm{NH} 4]^{+}$} & 212.0918 & $\begin{array}{c}748 \\
98\end{array}$ & 0.5 & $\mathrm{C}_{10} \mathrm{H}_{10} \mathrm{O}_{4}$ & 0.00168 \\
\hline \multicolumn{7}{|c|}{ Fatty acyls } \\
\hline Octyl acetate & {$[\mathrm{M}+\mathrm{K}]^{+}$} & 211.1095 & $\begin{array}{c}461 \\
96\end{array}$ & 0 & $\mathrm{C}_{10} \mathrm{H}_{20} \mathrm{O}_{2}$ & 0.00001 \\
\hline Caproic acid & {$[\mathrm{M}+\mathrm{K}]^{+}$} & 155.0469 & 111 & 0 & $\mathrm{C}_{6} \mathrm{H}_{12} \mathrm{O}_{2}$ & 7.38651e-6 \\
\hline 2-Tridecene-4,6,8-triyn-1-ol & {$[\mathrm{M}+\mathrm{H}]^{+}$} & 187.1119 & $\begin{array}{c}872 \\
96\end{array}$ & 1.1 & $\mathrm{C}_{13} \mathrm{H}_{14} \mathrm{O}$ & 0.00306 \\
\hline \multicolumn{7}{|c|}{ Fatty aldehydes } \\
\hline 2,4,7-tridecatrienal & {$[\mathrm{M}+\mathrm{H}]^{+}$} & 193.1589 & $\begin{array}{c}753 \\
53\end{array}$ & 1.5 & $\mathrm{C}_{13} \mathrm{H}_{20} \mathrm{O}$ & 0.00006 \\
\hline Tetradecadienal & {$[\mathrm{M}+\mathrm{H}]^{+}$} & 209.1902 & $\begin{array}{c}464 \\
61\end{array}$ & 1.4 & $\mathrm{C}_{14} \mathrm{H}_{24} \mathrm{O}$ & 0.00007 \\
\hline \multicolumn{7}{|c|}{ Glycerolipids } \\
\hline 1-Octylglycerol & {$[\mathrm{M}+\mathrm{K}]^{+}$} & 243.1357 & $\begin{array}{c}466 \\
20\end{array}$ & 0 & $\mathrm{C}_{11} \mathrm{H}_{24} \mathrm{O}_{3}$ & 0.00065 \\
\hline $\begin{array}{c}\text { Glyceryl 5- } \\
\text { hydroxydecanoate }\end{array}$ & {$[\mathrm{M}+\mathrm{Na}]^{+}$} & 285.1669 & $\begin{array}{c}883 \\
41\end{array}$ & -1.1 & $\mathrm{C}_{13} \mathrm{H}_{26} \mathrm{O}_{5}$ & 0.00301 \\
\hline \multicolumn{7}{|c|}{ Glycerophosphoglycerols } \\
\hline $\begin{array}{c}\mathrm{PE}(\mathrm{P}- \\
\text { 18:0/22:6(4Z,7Z,10Z,13Z,1 } \\
\text { 6Z,19Z)) }\end{array}$ & $\begin{array}{l}{[\mathrm{M}+\mathrm{H}-} \\
\mathrm{H} 2 \mathrm{O}]^{+}\end{array}$ & 758.5489 & $\begin{array}{c}467 \\
08\end{array}$ & 0 & $\begin{array}{c}\mathrm{C}_{45} \mathrm{H}_{78} \mathrm{NO}_{7} \\
\mathrm{P}\end{array}$ & $\begin{array}{c}\text { Down } \\
0.00220\end{array}$ \\
\hline $\begin{array}{c}\mathrm{PA}(13: 0 / 20: 5(5 Z, 8 Z, 11 Z, 14 \\
\mathrm{Z}, 17 Z))\end{array}$ & {$[\mathrm{M}+]$} & 652.4114 & $\begin{array}{c}812 \\
51\end{array}$ & -1.5 & $\mathrm{C}_{36} \mathrm{H}_{61} \mathrm{O}_{8} \mathrm{P}$ & 0.00001 \\
\hline PE(O-20:0/0:0) & $\mathrm{M}+2 \mathrm{Na}-\mathrm{H}$ & 540.3392 & $\begin{array}{c}777 \\
00\end{array}$ & -1.5 & $\begin{array}{c}\mathrm{C}_{25} \mathrm{H}_{54} \mathrm{NO}_{6} \\
\mathrm{P}\end{array}$ & 0.00219 \\
\hline \multicolumn{7}{|c|}{ Imidazopyrimidines } \\
\hline Adenine & {$[\mathrm{M}+\mathrm{H}]^{+}$} & 136.0618 & 85 & 0 & $\mathrm{C}_{5} \mathrm{H}_{5} \mathrm{~N}_{5}$ & 0.00005 \\
\hline Guanine & {$[\mathrm{M}+\mathrm{H}]^{+}$} & 152.0568 & 315 & 1.3 & $\mathrm{C}_{5} \mathrm{H}_{5} \mathrm{~N}_{5} \mathrm{O}$ & $4.68891 \mathrm{e}-6$ \\
\hline 6-Thiouric acid & {$[\mathrm{M}+\mathrm{NH} 4]^{+}$} & 202.0393 & 718 & 0 & $\begin{array}{c}\mathrm{C}_{5} \mathrm{H}_{4} \mathrm{~N}_{4} \mathrm{O}_{2} \\
\mathrm{~S}\end{array}$ & 0.00197 \\
\hline Hypoxanthine & {$[\mathrm{M}+\mathrm{H}]^{+}$} & 137.0458 & 83 & 0 & $\mathrm{C}_{5} \mathrm{H}_{4} \mathrm{~N}_{4} \mathrm{O}$ & 0.00110 \\
\hline \multicolumn{7}{|c|}{ Indoles and Derivatives } \\
\hline 3-Methylindole & {$[\mathrm{M}+\mathrm{H}]^{+}$} & 132.0809 & $\begin{array}{c}545 \\
3\end{array}$ & 1.5 & $\mathrm{C}_{9} \mathrm{H}_{9} \mathrm{~N}$ & 8.91649e-7 \\
\hline Indole & {$[\mathrm{M}+\mathrm{H}]^{+}$} & 118.0653 & 286 & 1.6 & $\mathrm{C}_{8} \mathrm{H}_{7} \mathrm{~N}$ & 0.00145 \\
\hline \multicolumn{7}{|c|}{ Lactams } \\
\hline Homoserine lactone & {$[\mathrm{M}+\mathrm{K}]^{+}$} & 140.0108 & $\begin{array}{c}658 \\
63\end{array}$ & 0 & $\mathrm{C}_{4} \mathrm{H}_{7} \mathrm{NO}_{2}$ & $8.96060 \mathrm{e}-6$ \\
\hline \multicolumn{7}{|c|}{ Lineolic acid and derivatives } \\
\hline octadecadienoic acid & {$[\mathrm{M}]^{+}$} & 312.2300 & 353 & 0 & $\mathrm{C}_{18} \mathrm{H}_{32} \mathrm{O}_{4}$ & 0.00002 \\
\hline
\end{tabular}




\begin{tabular}{|c|c|c|c|c|c|c|}
\hline & & & 48 & & & \\
\hline $\begin{array}{l}\text { 9-hydroperoxy-10E,12- } \\
\text { octadecadienoic acid }\end{array}$ & {$[\mathrm{M}]^{+}$} & 312.2300 & $\begin{array}{c}353 \\
48\end{array}$ & 0 & $\mathrm{C}_{18} \mathrm{H}_{32} \mathrm{O}_{4}$ & 0.0000054 \\
\hline \multicolumn{7}{|c|}{ Prenol lipids } \\
\hline $\begin{array}{l}\text { 2-Hexaprenyl-3-methyl-6- } \\
\text { methoxy-1,4-benzoquinol }\end{array}$ & {$[\mathrm{M}]^{+}$} & 562.4379 & $\begin{array}{c}628 \\
13\end{array}$ & -1.2 & $\mathrm{C}_{38} \mathrm{H}_{58} \mathrm{O}_{3}$ & 0.00028 \\
\hline \multicolumn{7}{|c|}{ Purine Nucleosides and Analogues } \\
\hline Adenosine & {$[\mathrm{M}+\mathrm{H}]^{+}$} & 268.1039 & 86 & -0.4 & $\begin{array}{c}\mathrm{C}_{10} \mathrm{H}_{13} \mathrm{~N}_{5} \mathrm{O} \\
4\end{array}$ & 0.00029 \\
\hline Guanosine & {$[\mathrm{M}+\mathrm{H}]^{+}$} & 284.0988 & 87 & -0.4 & $\begin{array}{c}\mathrm{C}_{10} \mathrm{H}_{13} \mathrm{~N}_{5} \mathrm{O} \\
5\end{array}$ & 0.00006 \\
\hline $\begin{array}{l}\text { Deoxyguanosine } \\
\text { Adenosine }\end{array}$ & $\begin{array}{c}{[\mathrm{M}+\mathrm{ACN}+} \\
\mathrm{H}]^{+}\end{array}$ & 309.1304 & $\begin{array}{c}339 \\
5\end{array}$ & -0.6 & $\begin{array}{c}\mathrm{C}_{10} \mathrm{H}_{13} \mathrm{~N}_{5} \mathrm{O} \\
4\end{array}$ & 0.00241 \\
\hline cGMP & {$[\mathrm{M}+\mathrm{H}]^{+}$} & 346.0541 & $\begin{array}{c}348 \\
5\end{array}$ & 1.7 & $\begin{array}{c}\mathrm{C}_{10} \mathrm{H}_{12} \mathrm{~N}_{5} \mathrm{O} \\
7 \mathrm{P}\end{array}$ & 0.00106 \\
\hline Isopentenyl adenosine & {$[\mathrm{M}+\mathrm{H}]^{+}$} & 336.1666 & $\begin{array}{c}640 \\
86\end{array}$ & 0 & $\underset{4}{\mathrm{C}_{15} \mathrm{H}_{21} \mathrm{~N}_{5} \mathrm{O}}$ & 0.00103 \\
\hline Xanthine & {$[\mathrm{M}+\mathrm{H}]^{+}$} & 153.0407 & 82 & 0 & $\mathrm{C}_{5} \mathrm{H}_{4} \mathrm{~N}_{4} \mathrm{O}_{2}$ & 0.0000053 \\
\hline 1-Methyladenosine & {$[\mathrm{M}+\mathrm{H}]^{+}$} & 282.1196 & $\begin{array}{c}688 \\
8\end{array}$ & 0 & $\underset{4}{\mathrm{C}_{11} \mathrm{H}_{15} \mathrm{~N}_{5} \mathrm{O}}$ & 0.00027 \\
\hline \multicolumn{7}{|c|}{ Pyrenes } \\
\hline Pyrene & $\begin{array}{c}{[\mathrm{M}+\mathrm{ACN}+} \\
\mathrm{H}]^{+}\end{array}$ & 244.1121 & $\begin{array}{c}699 \\
74\end{array}$ & 0 & $\mathrm{C}_{16} \mathrm{H}_{10}$ & 0.00048 \\
\hline \multicolumn{7}{|c|}{ Pyridines and Derivatives } \\
\hline Nicotinic acid (Niacin) & {$[\mathrm{M}+\mathrm{H}]^{+}$} & 124.0394 & 240 & 0.7 & $\mathrm{C}_{6} \mathrm{H}_{5} \mathrm{NO}_{2}$ & $2.46054 \mathrm{e}-6$ \\
\hline Pyridoxamine & $\begin{array}{c}{[\mathrm{M}+\mathrm{ACN}+} \\
\mathrm{H}]^{+}\end{array}$ & 210.1238 & 238 & 0.4 & $\mathrm{C}_{8} \mathrm{H}_{12} \mathrm{~N}_{2} \mathrm{O}_{2}$ & 0.00210 \\
\hline Pyridoxal (Vitamin B6) & $\begin{array}{c}{[\mathrm{M}+\mathrm{ACN}+} \\
\mathrm{H}]^{+}\end{array}$ & 209.0921 & $\begin{array}{c}220 \\
3\end{array}$ & 0 & $\mathrm{C}_{8} \mathrm{H}_{9} \mathrm{NO}_{3}$ & 0.00266 \\
\hline \multicolumn{7}{|c|}{ Pyrimidine Nucleosides and Analogues } \\
\hline $\begin{array}{l}\text { Cytidine diphosphate } \\
\text { choline }\end{array}$ & {$[\mathrm{M}+\mathrm{H}]^{+}$} & 489.1142 & $\begin{array}{c}358 \\
1\end{array}$ & -0.8 & $\begin{array}{c}\mathrm{C}_{14} \mathrm{H}_{26} \mathrm{~N}_{4} \mathrm{O} \\
{ }_{11} \mathrm{P}_{2}\end{array}$ & 0.00004 \\
\hline 2',3' cyclic CMP & {$[\mathrm{M}+\mathrm{H}]^{+}$} & 306.0481 & $\begin{array}{l}624 \\
29\end{array}$ & 1.3 & $\begin{array}{c}\mathrm{C}_{9} \mathrm{H}_{12} \mathrm{~N}_{3} \mathrm{O}_{7} \\
P\end{array}$ & $1.92863 \mathrm{e}-7$ \\
\hline
\end{tabular}


Table 2 Dysregulated metabolites in E.coli samples treated by clove oil and eugenol, obtained by HS-SPME GCxGC-ToFMS. Up-regulated metabolites are shown in red, while down-regulated metabolites are demonstrated in blue.

\begin{tabular}{|c|c|c|c|c|c|}
\hline Compound name & $\begin{array}{c}1^{\text {st }} \\
\text { dimention } \\
\text { r.t., } \\
2^{\text {nd }} \\
\text { dimension } \\
\text { r.t. }\end{array}$ & $\begin{array}{l}\text { Chemical } \\
\text { formula }\end{array}$ & $\begin{array}{c}\text { RI exp } \\
\text { (RI lit*) }\end{array}$ & $\begin{array}{c}\text { Molecular } \\
\text { weight } \\
\text { (Quantitation } \\
\text { ion) }\end{array}$ & $\begin{array}{c}\text { Regulation } \\
\mathbf{P}(\text { corr })\end{array}$ \\
\hline \multicolumn{6}{|c|}{ Alcohols } \\
\hline 1-butanol & $315,1.055$ & $\mathrm{C}_{4} \mathrm{H}_{10} \mathrm{O}$ & $\begin{array}{c}- \\
(675)\end{array}$ & $74.1(56)$ & 0.0753525 \\
\hline 2-methyl-1-butanol & $440,0.98$ & $\mathrm{C}_{5} \mathrm{H}_{12} \mathrm{O}$ & $\begin{array}{c}- \\
(739)\end{array}$ & $88.1(56)$ & 0.01631 \\
\hline Benzyl alcohol & $1005,1.495$ & $\mathrm{C}_{7} \mathrm{H}_{8} \mathrm{O}$ & $\begin{array}{c}1037 \\
(1037)\end{array}$ & 108(79) & 0.001539 \\
\hline 2-Heptanol & $765,0.795$ & $\mathrm{C}_{7} \mathrm{H}_{16} \mathrm{O}$ & $\begin{array}{c}903 \\
(905)\end{array}$ & $116.2(45)$ & 0.001413 \\
\hline 2-nonanol & $1115,0.75$ & $\mathrm{C}_{9} \mathrm{H}_{20} \mathrm{O}$ & $\begin{array}{c}1100 \\
(1098)\end{array}$ & $144.3(45)$ & 0.072198 \\
\hline 1-decanol & $1370,0.74$ & $\mathrm{C}_{10} \mathrm{H}_{22} \mathrm{O}$ & $\begin{array}{c}1273 \\
(1281)\end{array}$ & $158.3(55)$ & 0.04252 \\
\hline 2-undecanol & $1410,0.72$ & $\mathrm{C}_{11} \mathrm{H}_{24} \mathrm{O}$ & $\begin{array}{c}1300 \\
(1309)\end{array}$ & $172.3(45)$ & 0.053873 \\
\hline 2-tridecanol & $1670,0.695$ & $\mathrm{C}_{13} \mathrm{H}_{28} \mathrm{O}$ & $\begin{array}{l}1500 \\
(1510)\end{array}$ & $200.4(45)$ & 0.006879 \\
\hline \multicolumn{6}{|c|}{ Ketones } \\
\hline 2-Butanone & $240,0.695$ & $\mathrm{C}_{4} \mathrm{H}_{8} \mathrm{O}$ & $\begin{array}{c}- \\
(601)\end{array}$ & $72.1(72)$ & 0.009902 \\
\hline 3-hydroxy-2-butanone & $385,1.34$ & $\mathrm{C}_{4} \mathrm{H}_{8} \mathrm{O}_{2}$ & $\begin{array}{c}- \\
(712)\end{array}$ & $88.1(45)$ & 0.033523 \\
\hline 2-heptanone & $735,0.715$ & $\mathrm{C}_{7} \mathrm{H}_{14} \mathrm{O}$ & $\begin{array}{c}889 \\
(889)\end{array}$ & $114.2(58)$ & 0.008249 \\
\hline 2-undecanone & $1405,0.7$ & $\mathrm{C}_{11} \mathrm{H}_{22} \mathrm{O}$ & $\begin{array}{c}1297 \\
(1294)\end{array}$ & $170.3(58)$ & 0.120224 \\
\hline 2-tridecanone & $1660,0.69$ & $\mathrm{C}_{13} \mathrm{H}_{26} \mathrm{O}$ & $\begin{array}{c}1492 \\
(1496)\end{array}$ & 198.3 (198.3) & 0.000535 \\
\hline \multicolumn{6}{|c|}{ Esters } \\
\hline butyl acetate & $585,0.69$ & $\mathrm{C}_{6} \mathrm{H}_{12} \mathrm{O}_{2}$ & $\begin{array}{c}814 \\
(813)\end{array}$ & $116.2(56)$ & 0.006677 \\
\hline methyl hexanoate & $800,0.675$ & $\mathrm{C}_{7} \mathrm{H}_{14} \mathrm{O}_{2}$ & $\begin{array}{c}923 \\
(916)\end{array}$ & $130.2(74)$ & 0.006925 \\
\hline isoamyl acetate & $715,0.7$ & $\mathrm{C}_{7} \mathrm{H}_{14} \mathrm{O}_{2}$ & $\begin{array}{c}880 \\
(877)\end{array}$ & $130.2(55)$ & 0.001604 \\
\hline ethyl hexanoate & $940,0.695$ & $\mathrm{C}_{8} \mathrm{H}_{16} \mathrm{O}_{2}$ & $\begin{array}{c}997 \\
(999)\end{array}$ & $144.2(88)$ & 0.001018 \\
\hline methyl benzoate & $1105,0.82$ & $\mathrm{C}_{8} \mathrm{H}_{8} \mathrm{O}_{2}$ & $\begin{array}{c}1094 \\
(1103)\end{array}$ & 136.1 (136) & 4.33E-05 \\
\hline benzyl acetate & $1205,0.82$ & $\mathrm{C}_{9} \mathrm{H}_{10} \mathrm{O}_{2}$ & 1160 & $150.2(108)$ & 0.053059 \\
\hline
\end{tabular}




\begin{tabular}{|c|c|c|c|c|c|}
\hline & & & (1164) & & \\
\hline ethyl benzoate & $1215,0.825$ & $\mathrm{C}_{9} \mathrm{H}_{10} \mathrm{O}_{2}$ & $\begin{array}{c}1166 \\
(1171)\end{array}$ & $150.2(105)$ & 0.000837 \\
\hline 2-heptyl acetate & $1010,0.715$ & $\mathrm{C}_{9} \mathrm{H}_{18} \mathrm{O}_{2}$ & $\begin{array}{l}1040 \\
(1034)\end{array}$ & $158.2(87)$ & 0.00147 \\
\hline methyl octanoate & $1150,0.665$ & $\mathrm{C}_{9} \mathrm{H}_{18} \mathrm{O}_{2}$ & $\begin{array}{c}1124 \\
(1120)\end{array}$ & $158.2(74)$ & 0.009092 \\
\hline ethyl octanoate & $1255,0.645$ & $\mathrm{C}_{10} \mathrm{H}_{20} \mathrm{O}_{2}$ & $\begin{array}{c}1191 \\
(1190)\end{array}$ & $172.3(88)$ & 0.016902 \\
\hline 9-decen-1-yl acetate & $1540,0.685$ & $\mathrm{C}_{12} \mathrm{H}_{22} \mathrm{O}_{2}$ & $\begin{array}{c}1396 \\
(1399)\end{array}$ & $198.3(55)$ & 0.027809 \\
\hline n-decyl acetate & $1550,0.715$ & $\mathrm{C}_{12} \mathrm{H}_{24} \mathrm{O}_{2}$ & $\begin{array}{c}1404 \\
(1407)\end{array}$ & $200.3(70)$ & 0.079233 \\
\hline \multicolumn{6}{|c|}{ Aldehydes } \\
\hline furfural & $625,1.305$ & $\mathrm{C}_{5} \mathrm{H}_{4} \mathrm{O}_{2}$ & $\begin{array}{c}- \\
(895)\end{array}$ & $96.1(96)$ & 0.053183 \\
\hline benzaldeyde & $875,0.935$ & $\mathrm{C}_{7} \mathrm{H}_{6} \mathrm{O}$ & $\begin{array}{c}964 \\
(961)\end{array}$ & $106.1(106)$ & 0.043508 \\
\hline nonanal & $1115,0.675$ & $\mathrm{C}_{9} \mathrm{H}_{18} \mathrm{O}$ & $\begin{array}{c}1094 \\
(1103)\end{array}$ & $142.2(57)$ & 0.007613 \\
\hline \multicolumn{6}{|c|}{ Other chemical classes } \\
\hline $\begin{array}{l}\text { 4-(2,5-dihydro-3- } \\
\text { methoxyphenyl)butylamine }\end{array}$ & $1505,1.395$ & $\mathrm{C}_{11} \mathrm{H}_{19} \mathrm{NO}$ & $\begin{array}{c}1473 \\
(1480)\end{array}$ & $181.2(137)$ & 0.016093 \\
\hline $\begin{array}{l}\text { 1-(4- } \\
\text { hydroxybenzylidene)acetone }\end{array}$ & $1660,1.095$ & $\mathrm{C}_{10} \mathrm{H}_{10} \mathrm{O}_{2}$ & $\begin{array}{l}1493 \\
\text { (na) }\end{array}$ & $162.1(147)$ & 0.001157 \\
\hline methanethiol & $170,3.14$ & $\mathrm{CH}_{4} \mathrm{~S}$ & $\begin{array}{c}- \\
(500)\end{array}$ & $48.1(47)$ & 0.028055 \\
\hline 2-methoxy-2-methyl-propane & $220,0.62$ & $\mathrm{C}_{5} \mathrm{H}_{12} \mathrm{O}$ & $\stackrel{-}{-}(554)$ & $88.1(73)$ & 0.152448 \\
\hline thiazole & $440,1.035$ & $\mathrm{C}_{3} \mathrm{H}_{3} \mathrm{NS}$ & (743) & $85.1(58)$ & 0.007133 \\
\hline dimethyldisulfide & $440,0.76$ & $\mathrm{C}_{2} \mathrm{H}_{6} \mathrm{~S}_{2}$ & $\begin{array}{c}- \\
(747)\end{array}$ & $94.2(94)$ & 0.016498 \\
\hline 2,5-dimethyl-pyrazine & $785,0.795$ & $\mathrm{C}_{6} \mathrm{H}_{8} \mathrm{~N}_{2}$ & $\begin{array}{c}915 \\
(911)\end{array}$ & $108.1(108)$ & 0.158593 \\
\hline indole & $1415,1.85$ & $\mathrm{C}_{8} \mathrm{H}_{7} \mathrm{~N}$ & $\begin{array}{c}1303 \\
(1303)\end{array}$ & $117.2(107)$ & 0.278593 \\
\hline $\begin{array}{l}\text { trans-1,3-dimethyl-2- } \\
\text { methylenecyclohexane }\end{array}$ & $830,0.7$ & $\mathrm{C}_{9} \mathrm{H}_{16}$ & $\begin{array}{l}940 \\
\text { (na) }\end{array}$ & $124.2(83)$ & 3.55E-05 \\
\hline 2-pentyl-furan & $925,0.645$ & $\mathrm{C}_{9} \mathrm{H}_{14} \mathrm{O}$ & $\begin{array}{l}990 \\
\text { (na) }\end{array}$ & $138.2(81)$ & 0.00299 \\
\hline $\begin{array}{l}\text { 2-ethenyl-1,1-dimethyl-3- } \\
\text { methylidenecyclohexane }\end{array}$ & $1130,0.64$ & $\mathrm{C}_{11} \mathrm{H}_{18}$ & $\begin{array}{c}1110 \\
\text { (na) }\end{array}$ & $150.3(69)$ & 0.129196 \\
\hline 2,3,5,8-tetramethyl-decane & $1365,0.65$ & $\mathrm{C}_{14} \mathrm{H}_{30}$ & $\begin{array}{l}1269 \\
\text { (na) }\end{array}$ & $198.4(57)$ & 0.007477 \\
\hline
\end{tabular}


